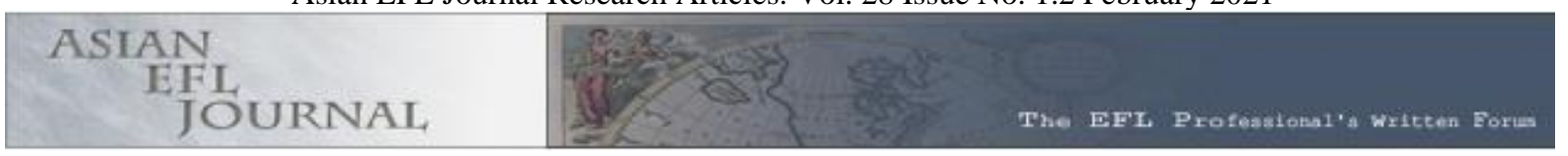

\title{
Constructing WhatsApp-based Speaking Instructional Material (WABSIM) for EFL Teaching and Learning: A Need Analysis
}

\author{
${ }^{1}$ Maulina, ${ }^{2}$ David Geelan, ${ }^{3}$ Muhammad Basri, ${ }^{4}$ Nurdin Noni \\ ${ }^{1}$ Muhammadiyah University of Kendari, Indonesia \\ ${ }^{2}$ Griffith University, Australia \\ ${ }^{3 \& 4}$ State University of Makassar, Indonesia \\ Corresponding Author: lina821431@yahoo.com
}

\section{Bio-profiles:}

Maulina is a lecturer at the English Education Study Program, Faculty of Teacher Training and Education, Muhammadiyah University of Kendari, Indonesia. She has been presenting some of her research articles in TESOL conference in partnership with Universitas Negeri Makassar, ASIA TEFL conference in Macau, China, TEFLIN conference, $2^{\text {nd }}$ international virtual conference, the Asian ESP Journal and Asian EFL Journal international virtual conference, and some more. She has also been awarded scholarship from the Indonesian Ministry of Research, Technology, and Higher Education in her Doctoral study under Beasiswa Unggulan Dosen Indonesia Dalam Negeri (BUDIDN) granted by the Indonesia Endowment Fund for Education (LPDP) and also she got a scholarship to write research articles for international publication in Griffith University, Australia. Her research interests lie in English language teaching methodologies, instructional materials development, mobile learning, gender issues, new technology use in EFL teaching, and social media in EFL teaching and learning. She can be reached at lina821431@yahoo.com.

David Geelan is an Associate Professor in Science Education at Griffith University in Gold Coast Campus, Australia. His research interests include science education, educational technology, interactive simulations, and teacher explanations. David Geelan can be reached at d.geelan@griffith.edu.au. 
Muhammad Basri is a Professor in the English Education Study Program at State University of Makassar. He is currently the Head of English Education Study Program for Doctoral Program as well as the Co-Promoter of the first author of this paper. He teaches courses related to English skills. His research interests include materials development, multimedia learning materials in teaching English speaking, and applied linguistics. His email is muhammadbasri@unm.ac.id.

Nurdin Noni is a Professor in the English Education Study Program at State University of Makassar. He is the Promoter of the first author of this paper. He teaches courses related to Information and Communication of Technology (ICT) in English as a foreign language teaching. His main research is ICT in EFL teaching. His email is nurdinnoni@yahoo.com.

\begin{abstract}
Today's English teaching and learning speaking in the digital era at the university level is full of challenges but promotes many possibilities. WhatsApp, the most popular social media used for communication, can be interactively utilized to study speaking about daily conversations in a flexible way anytime and anywhere to solve students' speaking problems as well as one of the teaching and learning media in the disruptive era. This research was trying to develop WhatsApp-based speaking instructional material (WABSIM) for the Basic Speaking subject to help students speaking English effortlessly and fast about daily topics. This research was the first step of Research and Development (R\&D) of the ADDIE model i.e., to analyze students' needs to learn Basic Speaking through WhatsApp instructions. The research took place at the English Education Study Program of one private university in South East Sulawesi, Indonesia. Sixty-eight (68) students participated in giving information regarding to the students' needs through an online survey in the Google Form. It revealed that students wanted to learn the Basic Speaking materials integrated with mobile technology in the form of social media of WhatsApp to make the learning is fast, enjoyable, fun, more communicative, more collaborative, and help them learning anytime anywhere, in and outside the classroom more independently. Also, students need real-life topics, authentic, interactive, and presenting domestic and international viewpoints in the WABSIM. Besides, the developed speaking materials should cover the audio and visual materials to cover students' learning styles varieties, and the materials should include the speaking components such as vocabulary, grammar, pronunciation, fluency, comprehension, and task. Data resulting from the needs analysis informed the researchers of crucial issues to consider in developing WABSIM for the
\end{abstract}


design, development, implementation, and evaluation in the next phase of this project. Further, students' preferences and learning goals can be integrated with perspectives from the mobile learning literature and the affordances of WhatsApp to facilitate communication, collaboration and interaction in ways that have the potential to accelerate English language learning on the part of university students. There would be value in conducting similar needs analyses for other mobile learning instructional material development processes internationally, both for comparison with the Indonesian results here and in order to inform those development processes.

Keywords: Need analysis, mobile technology, social media, speaking skill, WhatsApp, WABSIM

\section{Introduction}

Mobile learning is considered to have potential as today's learning model. Mobile technologies allow learning anytime and anywhere (Popescu, 2011, p.90) and can support lifelong learning. According to Arif (2019), an innovative revolutionary approach towards learning is identified through mobile in this $21^{\text {st }}$ era. A needs analysis was conducted to determine the speaking models, speaking situations, speaking styles, speaking components, speaking contents, speaking contexts, speaking topics, speaking activities, and speaking material adaptation in the form of WhatsApp-based (WAB) instruction that suit with challenges and opportunities offered in this era. Instructional approach is crucial and it helps educator meets students' needs in learning activities (Maming, et al., 2020).

Karademir, et al (2019) suggests that a platform for English language learning is needed particularly speaking materials which enable students to access them anytime, anywhere. This allows students to communicate actively, build confidence in speaking, extend their learning and flip the speaking classroom. A few studies have explored the provision of English teaching materials in general, but none has developed instructional materials for teaching speaking skills for university students using WhatsApp (Speroff, 2016).

Kukulska-Hulme et al. (2015) argue that mobile technologies in the classroom provide an additional platform for interaction and communication and that these technologies expand and extend the territory where language can be rehearsed and practiced. By developing materials based on a need analysis, it is expected that it will be possible to actively engage the students to communicatively perform oral communication in English in their day to day interactions both on campus and in society more generally. This frequent practice in authentic 
contexts has the potential to promote students' independent learning, motivation, and enhance their speaking skills (Maulina, Noni, Basri, 2019). The findings of this analysis, the proposed speaking module called WhatsApp-Based speaking module (WABSIM) is developed and evaluated.

\section{Literature Review}

\section{Social Media in EFL Teaching}

Social media differ from traditional or industrial media in many ways, including quality, frequency, usability, immediacy, and permanence. Social media operate in a dialogic transmission system (many sources to many receivers) (Pavlik \& MacIntoch, 2015). Social media like Twitter, Facebook, and Instagram are primarily used as media for sharing pictures and text (Munir, 2017) while WhatsApp, Facebook chat, BBM, LINE, Yahoo Messenger, and Skype are chatting media (p.75). Kietzmann, Hermkens, McCarthy, and Silvestre (2011, pp. 243-247) present a framework that defines social media using seven functional building blocks: identity, conversations, sharing, presence, relationships, reputation, and groups.

One of research sample of developing learning resource integrated with the social media in EFL teaching was a research by Sakkir (2017). She conducted a study on the use of Facebook in developing writing instructional material. This work revealed that students in the English Department at STKIP Muhammadiyah Rappang achieved significant writing achievement improvement through using Facebook. She found that writing material developed via Facebook can assist students in solving their writing problems, and that the students highly valued the use of Facebook in teaching English writing.

WhatsApp, the most popular social media among undergraduate students according to Ahad and Lim (2014), could positively influences students' ability to speak daily topics and connect with peers online anytime, anywhere, and to anyone. Minalla (2018) states that WhatsApp, especially WhatsApp groups, can reinforce EFL learners' verbal interactions beyond the classroom context, which means that learners can be independent in learning with the materials. Vygotsky's Constructivist Learning Theory (1978) suits the use of WhatsApp. This theory aims to develop the students' social interaction as well as to raise and share information.

\section{Need Analysis}

Brown (1995) identifies the term 'needs analysis' (also called 'needs assessment') in an educational context in terms of the activities involved in gathering information that will 
serve as the basis for developing a curriculum which meets the learning needs of a particular group of students. Piskurich (2015, p. 90-92) proposes that there are two types of needs analysisespecially in relation to instructional material development namely audience analysis and learning analysis.

Audience analysis (which in this research is called 'student needs analysis) is done prior to learning and product analysis in designing a program. According to Piskurich (2015) audience analysis aspects include age, gender, educational experience, interests, prerequisite knowledge and skills, and many other characteristics that can help the designer to properly evaluate both the learner and the program (p.92).

In addition, Piskurich $(2015$, p.90) proposes that learning analysis is done through three processes: (1) working with the manager (which in this research is working with the lecturers to define what required, (2) gathering data concerned with the program of developing the instructional material, and (3) analyzing the possible learning to decide which of them the program must cover. The topic, learning objectives, task, content, procedures, and additional information to support the content are considered in doing the learning analysis.

\section{Table 1}

Aid proposed by Piskurich (2015, pp. 103-104)

\begin{tabular}{|c|c|c|c|c|}
\hline Type & Purpose & Sequence & Best Method & Product \\
\hline $\begin{array}{l}\text { Audience } \\
\text { Analysis/students } \\
\text { need analysis }\end{array}$ & $\begin{array}{l}\text { To determine the } \\
\text { characteristics of } \\
\text { the target learners } \\
\text { that will be } \\
\text { critical for } \\
\text { program } \\
\text { development }\end{array}$ & $\begin{array}{l}\text { Might be done } \\
\text { anytime during } \\
\text { the design } \\
\text { process, but } \\
\text { always before } \\
\text { developing } \\
\text { program material }\end{array}$ & $\begin{array}{l}\text { Questionnaire } \\
\text { and } \\
\text { interviews } \\
\text { with learners } \\
\text { and others } \\
\text { who know the } \\
\text { students' } \\
\text { characteristics }\end{array}$ & $\begin{array}{l}\text { A list of general } \\
\text { characteristics } \\
\text { that the designer } \\
\text { needs to } \\
\text { consider when } \\
\text { creating course } \\
\text { material }\end{array}$ \\
\hline $\begin{array}{l}\text { Learning } \\
\text { Analysis/learning } \\
\text { needs analysis }\end{array}$ & $\begin{array}{l}\text { To discover the } \\
\text { learning needs of } \\
\text { the organization, } \\
\text { a work group or } \\
\text { individual } \\
\text { contributors } \\
\text { To determine the } \\
\text { critical learning } \\
\text { necessary to meet } \\
\text { a training need }\end{array}$ & $\begin{array}{l}\text { This is done in } \\
\text { the beginning } \\
\text { before designing } \\
\text { the program or } \\
\text { Done in lieu of } \\
\text { job analysis }\end{array}$ & $\begin{array}{l}\text { Interview or } \\
\text { focus group }\end{array}$ & $\begin{array}{l}\text { A list of training } \\
\text { needs for the } \\
\text { targeted level of } \\
\text { the analysis and } \\
\text { a determination } \\
\text { of which of } \\
\text { those needs } \\
\text { might be } \\
\text { addressed. } \\
\text { A prioritized list } \\
\text { of the critical } \\
\text { learning that }\end{array}$ \\
\hline
\end{tabular}




\begin{tabular}{|c|c|c|c|c|}
\hline Type & Purpose & Sequence & Best Method & Product \\
\hline & & & & $\begin{array}{l}\text { must be } \\
\text { mastered to meet } \\
\text { the needs. }\end{array}$ \\
\hline
\end{tabular}

In the analysis phase, educators verify the needs of the students in order to determine the educational objectives and what needs to be taught to achieve the educational goals. In this study, two kinds of analyses consisting of audience analysis and learning analysis proposed by Piscurich (2015) were used to identify common characteristics of the students and the critical learning needs to inform the development of a set of WhatsApp-based speaking instructional materials.

\section{Research Methods}

Research Design

In conducting a needs analysis as the first step to develop the WABSIM, researchers adopted an 'ADDIE' approach as a research and development (R\&D) model. ADDIE stands for Analyze, Design, Develop, Implement, and Evaluate. The ADDIE model is an iterative instructional design process, where the results of the formative evaluation of each phase may lead the instructional designer back to the previous phase. The end product of one phase is the starting product of the next phase.

This paper is focused on the 'Analyze' phase as the fundamental point before designing, developing, implementing, and evaluating the intended teaching and learning module used for EFL teaching in an Indonesian university.

\section{Participants}

Sixty eight students who agreed to participate as respondents in this research were from the third and the fifth semester students of the English Education Department of Muhammadiyah University of Kendari in the academic year 2018-2019. These respondents have had experienced about the teaching and learning of the Basic Speaking course previously in the second semester. They have had the perspectives about the lesson was.

\section{Research Instrument}

An online questionnaire used in this study was in the form of a Google Form. To gain data about students' needs for developing the WABSIM for Basic Speaking subject; researchers modified a questionnaire from Munby's (1978), Thronburry (2005), Piskurich 
(2015). The questionnaires were posted and filled out online through the Google Form. The form is captured in Figure 1.

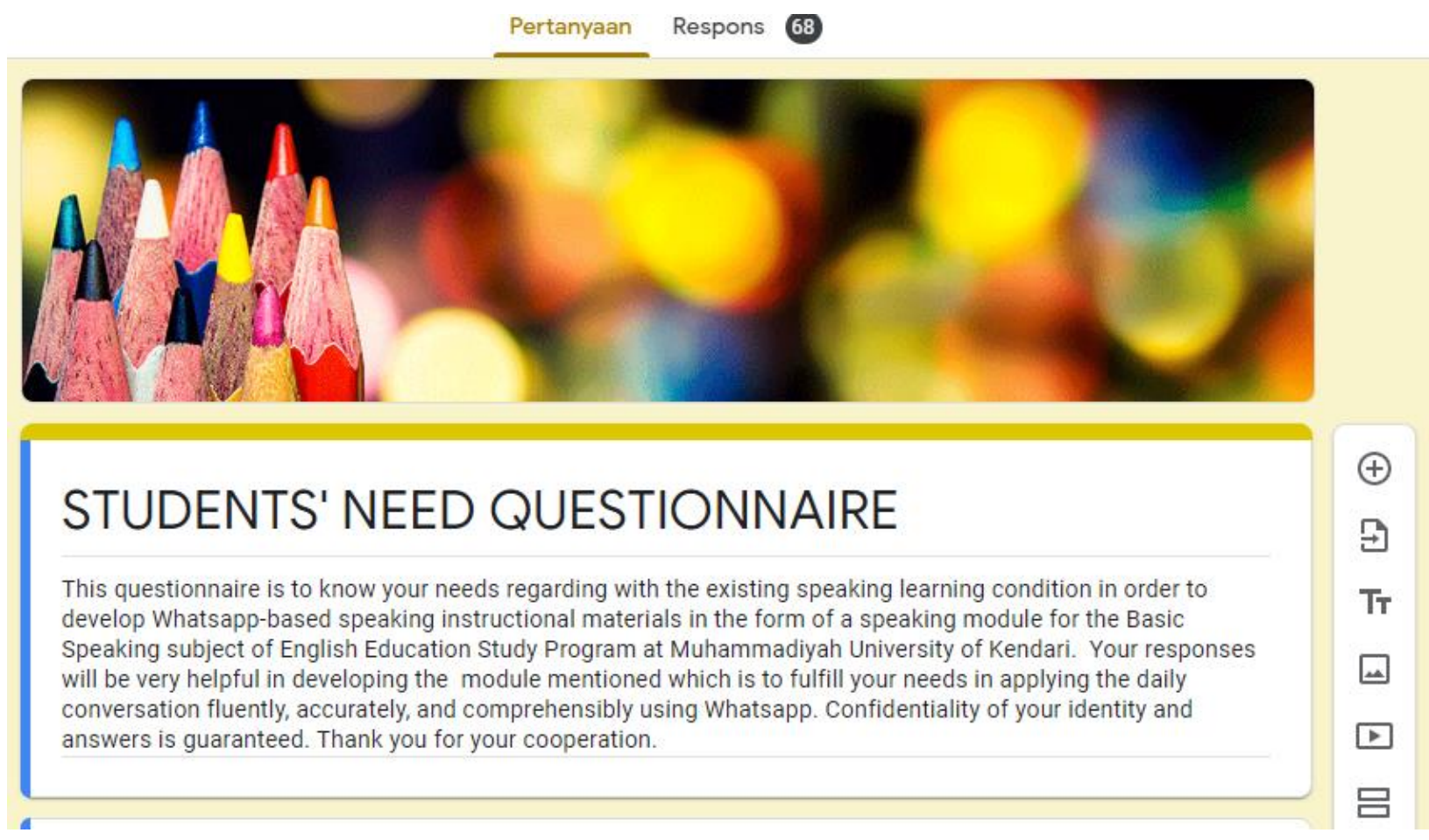

Fig. 1 Students' Need Questionnaire

\section{Data Collection}

The questionnaire for the student needs analysis and the learning needs analysis was distributed and responded using a Google form, with a link to access the form shared through the WhatsApp group. Responses from students about their learning needs were in the form of Likert Scale. Students' demographics analysis cover the information about age, gender, speaking background experiences using WhatsApp on campus and outside of campus. In addition, students' learning needs analysis include target needs: speaking model, speaking situation, speaking component, speaking content, speaking context, speaking activities, speaking topics, as well as speaking material adaptation and readiness to study Basic Speaking unit lesson via WhatsApp-based instruction.

\section{Data Analysis}

The data were collected through a survey instrument composed of Likert Scale and other items, hosted on Google Forms. These data are represented in Tables 1-8 as both tallies of participants selecting a particular response and as percentages, and were interpreted qualitatively to inform the development of the proposed WABSIM for Basic Speaking.

\section{Findings and Discussion}


The students' needs analysis was the first step of the Research and Development model (R\&D). Students' need analysis is crucial as the feasibility of a product should also be measured by the demands and needs of the users. In measuring the needs of the students, the researcher tried to find out the present condition of the students' capabilities in learning English, especially speaking and also their expectation. It includes their objectives in learning English, how they think English material should be delivered in terms of language orientation, the endorsement of the four language skills within the course, the learning topics, and their learning preferences. By the needs analysis, a researcher can design any materials which meet the learning needs. A needs analysis step was suggested by some researchers and experts on material development (Richards, 2001; Nation, 2010). They argued that it is imperative for conducting needs analysis before designing any materials, whether for English for Occupational Purposes (EOP), English for Academic Purposes (EAP), and General English (GE).

\section{Students’ Demographics Analysis}

Based on Table 3.1, it shows that $17.6 \%$ of students aged $18,41.2 \%$ of students aged $19,33.8 \%$ of students were aged $20,4.4 \%$ of students were aged 22 , and $2.6 \%$ were 21 . Also, it shows that female students were the most dominant in this study, i.e., $83.8 \%$ and male students were only $16.2 \%$. This is the phenomenon at this moment that female students who are enrolling in studying English at the English Education Department at the Muhammadiyah University of Kendari are the majority representative participants. They aged from eighteen to twenty-two. The majority of female students as the participant who took the role in this study did not guarantee that female students were not more superior to male like gender differences in language production (Maulina, 2018).

\section{Table 1}

Participant Demographics

\begin{tabular}{|c|c|c|c|c|}
\hline No & Information & Answer & Frequency & Percentage \\
\hline \multirow[t]{5}{*}{1} & Age & 18 & 12 & 17.6 \\
\hline & & 19 & 28 & 41.2 \\
\hline & & 20 & 23 & 33.8 \\
\hline & & 21 & 2 & 2.9 \\
\hline & & 22 & 3 & 4.4 \\
\hline 2 & Gender & Male & 11 & 16.2 \\
\hline
\end{tabular}




\begin{tabular}{lllll}
\hline No & Information & Answer & Frequency & Percentage \\
\hline & Female & 57 & 83.8 \\
\hline
\end{tabular}

Today's students are familiar enough with the social media called WhatsApp. The students in this study brought their smartphone to college every day to stay connected with friends, lecturers, and family members. Students in this study were very familiar with smartphones and had installed WhatsApp and used it daily already on campus and outside of campus, as seen in Table 2 as a part of this analysis.

\section{Table 2}

WhatsApp Use in Campus and Outside of Campus

\begin{tabular}{lllll}
\hline No & Information & Answer & Frequency & Percentage \\
\hline 1 & How often do you speak & Always & 1 & 1.5 \\
& English on campus via & Usually & 17 & 25 \\
& WhatsApp? & Sometimes & 42 & 61.8 \\
& Seldom & 7 & 10.3 \\
& Never & 1 & 1.5 \\
2 & How often do you speak & Always & 0 & 0 \\
& English outside of the campus & Usually & 12 & 17.6 \\
& via WhatsApp? & Sometimes & 43 & 63.2 \\
& & Seldom & 12 & 17.6 \\
& & Never & 1 & 1.5 \\
\hline
\end{tabular}

Table 2 shows the students' speaking experiences in the aspect of using English via WhatsApp at college and outside of the college. $60 \%$ of students liked to communicate via WhatsApp, both on campus and outside of campus. The remaining $25 \%$ of students frequently used English when they were at the campus. Also, $17.6 \%$ of students tended to communicate orally through WhatsApp when they were outside of campus, for example, at home. It indicates that students in this research have been familiar with the friendly-user, cheap, and fast access to WhatsApp. The popularity of group communication in WhatsApp encourages students to work on the tasks assigned, particularly for daily conversation collaboratively and communicatively in a fast connection. This study is in line with the findings by Awada (2016), Mackey (2016), Yafuz (2016), Afful and Akrong (2019), and Madge et al. (2019). Students' familiarity in this mobile platforms enable them stay connected with friends, lecturers, and 
family members as well as make them studying both in an asynchronous and synchronous pace and time.

\section{Students' Learning Needs Analysis}

There were nine aspects to know students' want, need, requirement, or necessity of the WABSIM. The aspects were speaking models, speaking situations, speaking styles, speaking components, speaking contents, speaking contexts, speaking topics, speaking activities, and speaking material adaptation in the form of WAB instruction discussed as follows.

\section{Speaking Model}

WAB speaking models are designed based on the students' wants. Face to face communication and distance communication through social media like WhatsApp, in and outside the classroom, guide students to get varieties of the speaking situation and get more speaking engagement that they can reduce anxiety to talk in English. WhatsApp speaking models that students preferred to apply in the Basic Speaking course is described in Table 3.

\section{Table 3}

WhatsApp Learning Model Needed

\begin{tabular}{|c|c|c|c|c|}
\hline No & Information & Answer & $\mathbf{F}$ & $\%$ \\
\hline \multirow[t]{8}{*}{1} & WhatsApp Speaking & WhatsApp audio call & 11 & 16.2 \\
\hline & model & WhatsApp video call & 3 & 4.4 \\
\hline & & Both WhatsApp audio and video call & 6 & 8.8 \\
\hline & & WhatsApp audio recording & 35 & 51.5 \\
\hline & & WhatsApp video recording & 13 & 19.1 \\
\hline & & Both WhatsApp audio and video recording & 19 & 27.9 \\
\hline & & WhatsApp written chats individually & 1 & 1.5 \\
\hline & & WhatsApp written chats in groups & 1 & 1.5 \\
\hline
\end{tabular}

Note: students could choose more than one responses for this part

Table 3 shows that the speaking models that students would like to apply when speaking English via WhatsApp. Students were allowed to prefer more than one option in choosing their preferences. 51.5\% of students preferred to speak English through WhatsApp audio recording (WAAR). Then, $19.1 \%$ of students wanted to speak English via WhatsApp video recording (WAVR), and $27.9 \%$ of them liked to talk in the WhatsApp using both audio and video recording. The lowest percentages showed for WhatsApp audio and video calling WAAC and 
WAVC), i.e., $8.8 \%$. The speaking materials which need to be developed must meet the students' learning needs by providing audio and video recording materials as examples for them to do speaking instructions during and after the lesson tasks and to imitate the model speaking naturally.

\section{Speaking Situation}

The information in Table 4 shows that most of the students (70.1\%) supported using both formal and informal speaking situations in the speaking instructional materials developed for the next phase. $50 \%$ of students demanded to speak in two ways, namely, both with one person and in a group. The remaining $20.6 \%$ of students individually preferred only speaking with one person via WhatsApp, and $29.4 \%$ preferred in groups.

\section{Table 4}

Speaking Situation

\begin{tabular}{|c|c|c|c|c|}
\hline No & Information & Answer & Frequency & $\%$ \\
\hline \multirow[t]{3}{*}{1} & English speaking & Formal & 8 & 11.9 \\
\hline & skill needed & Informal & 12 & 17.9 \\
\hline & & Both formal and informal & 47 & 70.1 \\
\hline \multirow[t]{3}{*}{2} & Speaking share & With one person & 20 & 29.4 \\
\hline & model 1 & In groups & 14 & 20.6 \\
\hline & & Both with one person and in groups & 34 & 50 \\
\hline \multirow[t]{3}{*}{3} & Speaking share & With the same person all the time & 15 & 22.1 \\
\hline & model 2 & With different people all the time & 13 & 19.1 \\
\hline & & $\begin{array}{l}\text { Both with the same person and with different } \\
\text { people }\end{array}$ & 40 & 58.8 \\
\hline
\end{tabular}

WhatsApp as a social medium enables students to collaborate, communicate, and connect with one person at the same time or at the particular times, and also with a group of people in the form of a group WhatsApp. Both formal and informal learning materials will be provided in balance when the materials are in the design and development phase. Such speaking models are designed to allow learners to be able to use various types of reasoning as appropriate to the situation in their speaking exercises and solve different kinds of daily topics in innovative ways. Speaking situations can be explicitly designed by mixing formal and informal situations 
for students to be able to lead students to prepare themselves easy in self-adapting the communication situation.

\section{Speaking Styles}

There are four kinds of students in learning speaking. Some students like to study speaking visually. They liked to see images, videos, audios, illustrations provided in the material. Besides, some students liked both audio and visual items during the learning, and some like to act out. Further, the rest accept all kinds of speaking learning styles. In this research, the percentages of students speaking learning styles are provided in Table 5 as follows.

\section{Table 5}

Speaking Styles

\begin{tabular}{llll}
\hline No & Information & Frequency & \% \\
\hline 1 & Audio & 20 & 29.9 \\
2 & Visual & 9 & 13.4 \\
3 & Audiovisual & 18 & 26.9 \\
4 & Kinesthetic & 1 & 1.5 \\
5 & All four styles & 19 & 28.4 \\
\hline
\end{tabular}

Having the result of seeing students' speaking learning styles, the researcher assumed that in learning Basic Speaking, students needed WAB speaking material in the form of audio (29.9\%) and audiovisual (26.9\%). Also, they needed a kind of visual material (13.4\%) in the module that was going to develop. It was quite a minor kind of student who liked to act out speaking learning (1.5\%). However, some students liked to put all the learning styles together when learning Basic Speaking (28.4\%). Further, students need speaking materials that enable them to produce communicatively and collaboratively actively. Those kinds of speaking learning styles are essential to consider in developing the WABSIM for Basic Speaking subject. Students' speaking learning styles are considered for designing WABSIM that the materials can cover and meet students' learning preferences. Vocabulary lists, reading texts, Audio, videos, and other illustrations need to be provided.

Speaking learning materials bring those students in heterogonous styles effectively comprehend the learning. Original and authentic speaking materials are helpful and will familiarize students with the natural way of learning speaking, talking about daily conversation. 
Speaking activities are designed to motivate students with different learning styles to manage and demonstrate the inside and outside WAB speaking tasks effectively. The design of the speaking tasks ensures each student participates actively and cooperates effectively with teams. Individual accountability and commitment play an essential role in handling various English tasks (Albino, 2017; Astuti \& Lammers, 2017). They further disclose that when students were believed to handle more than one English task, they produced spoken English more and got comprehensible inputs. The findings from this study affirm that the students' learning styles are identified as communicative and concrete learners (Willing, 1988) because the students' learning styles are fit in type to the characteristics of the four learning styles.

\section{Speaking Component}

There are six speaking components (Brown, 2004): pronunciation, grammar, vocabulary, fluency, comprehension, and task.

\section{Table 6}

Speaking Component

\begin{tabular}{lllll}
\hline No & Information & Answer & Frequency & Percentage \\
\hline 1 & Speaking components & Pronunciation & 28 & 41.2 \\
& to be improved & Grammar & 26 & 38.2 \\
& & Vocabulary & 31 & 45.6 \\
& & Fluency & 14 & 20.6 \\
& & Comprehension & 9 & 13.2 \\
& & Task & 11 & 16.2 \\
& & All components & 32 & 47.1 \\
\hline
\end{tabular}

"Note: students could choose more than one responses for this question

Table 6 is about speaking components that the students would like to improve in learning Basic Speaking via WhatsApp-Based Instruction. There were six speaking components to be improved during their learning Basic Speaking using WhatsApp as the medium to help them associate their vocal performances daily on campus and outside of the campus. Firstly, $45.6 \%$ of students agreed that they desired to improve their vocabulary. It followed by pronunciation with $41.2 \%$ agreed in this component. Then, they also agreed to enhance their grammar with 38.2\%. Further, fluency (20.6\%), task (16.2\%), and comprehension (13.2\%). $47.1 \%$ of students agreed that it was important to improve the six components. Therefore, speaking components that most prioritized in the development phase were vocabulary, pronunciation, grammar, fluency, task, and comprehension aspects. Brown 
(2004) argue that including these six elements in the speaking curriculum and their mastery by students becomes the key for both educators and students to effectively use in communication.

\section{Speaking Content, Context, and Activities}

Table 7 shows the content of WhatsApp-based speaking instructions that must be involved in the next stage, namely designing and developing the speaking instructional materials. Half of the students $(52.9 \%)$ who responded this questionnaire agreed that both written and audio/video dialogue of daily conversation topics with an easy grammar and vocabulary content must be provided in the learning materials. $25 \%$ of students agreed with written dialogue, and $22.1 \%$ agreed with the audio and video speaking materials. Furthermore, it shows that $57.4 \%$ of students agreed with the context of overseas speaking learning topics, and $42.6 \%$ agreed with domestic topics. In addition, it shows that students liked to do speaking activities when studying daily conversation topics for Basic Speaking subject via WhatsAppbased instructions in the form of groups $(57.4 \%)$, in pairs $(45.6 \%)$, role plays $(30.9 \%)$, and small interviews (23.55), 17.6\% of students wanted to apply the five activities integrated during their learning. The least preference appeared with the demonstration activity, namely $2.9 \%$.

\section{Table 7}

Speaking content, context, and activity

\begin{tabular}{|c|c|c|c|c|}
\hline No & Information & Answer & Frequency & Percentage \\
\hline \multirow[t]{3}{*}{1} & Speaking instruction content & $\begin{array}{l}\text { Written dialogue of daily } \\
\text { conversation topics with an } \\
\text { easy grammar and vocabulary } \\
\text { content }\end{array}$ & 15 & 22.1 \\
\hline & & $\begin{array}{l}\text { Audio/video dialogue of daily } \\
\text { conversation topics with an } \\
\text { easy grammar and vocabulary } \\
\text { content }\end{array}$ & 17 & 25 \\
\hline & & $\begin{array}{l}\text { Both written and audio/video } \\
\text { dialogue of daily conversation } \\
\text { topics with an easy grammar } \\
\text { and vocabulary content }\end{array}$ & 36 & 52.9 \\
\hline \multirow[t]{2}{*}{2} & Speaking context & Domestic & 29 & 42.6 \\
\hline & & Overseas & 39 & 57.4 \\
\hline
\end{tabular}




\begin{tabular}{lllll}
\hline No & Information & Answer & Frequency & Percentage \\
\hline \multirow{3}{*}{3} & \multirow{2}{*}{ Speaking activities } & Dialogue in pairs & 32 & 45.6 \\
& & Dialogue in groups & 39 & 57.4 \\
& & Role plays & 21 & 30.9 \\
& & Interviews & 16 & 23.5 \\
& & Demonstrations & 2 & 2.9 \\
& & All five activities integrated & 12 & 17.6 \\
\hline
\end{tabular}

Note: students could choose more than one responses for question 4

First of all, Contents are in line with the relevant technologies utilizing WhatsApp and additional listening resources from videos in the learning process. Those technologies have been a great inspiration for students and have made them want to learn more about learning materials (Bahadorfar \& Omidvar, 2014). These technological tools are much more exciting and provide fun and enjoyable learning, thus, motivating them and helping them to enhance their language learning fruitfully. Moreover, these tools help students learn at their own pace and promote autonomy in them. Contents of the Basic Speaking is by providing both audio and video recording materials as the examples for them to do speaking instructions during and after the lesson tasks as well as to imitate the model speaking naturally.

Secondly, domestic and international contexts of materials enable students to enrich their insights as well as put students to culturally aware of both the context. Both daily domestic issues and international issues would like to be selected carefully in order that students can show their confidence when doing speaking activities. The material presented will be covering two settings, domestically and internationally, in the form of illustrations, figures, photos, videos, and more. In the WAB Basic Speaking materials, the researcher presented a learning context in a familiar situation, both domestic and international issues that suits students' needs.

In this research, students' wants that both local and international context must be explicitly written in the WAB speaking instructional material. It is how including the communicative and collaborative speaking activities that students could think to learn both cultural values in talking about daily topics. The communicative and collaborative contexts work to effectively manage students to be aware of the technology used to think in solving several speaking problems and understand how to work effectively in preparation for their advanced speaking level and future career. Students' wants were supported by the interview results from the speaking lecturers, which highlighted that the material of Basic Speaking course must be explicitly written about the 21 st-century skills demand in both contexts, local and international. It is in line with Tomlinson (2011) who stated that the content of the 
instructional material developed should be contextualized to reverse the local and global world where the teachers and students live in. The mixing context of speaking material designed to support learners to be able to interact effectively with others (i.e., know when it is appropriate to listen and when to speak, respond open-mindedly to different ideas, and leverage social and cultural differences to create new ideas in speaking exercises and tasks). The exercises related to cross-cultural materials help prepare students to understand and develop skills and abilities in cultural diversity, intercultural communication, empathy, aptitudes for working collaboratively and networking across cultures and interacting with people from different social and cultural backgrounds (Sun, 2015).

Furthermore, It is crucial to prioritize the most until the least speaking activities that must be in the learning material. Therefore, the researcher would like to create materials with lots of group and pair activities followed by small interview activities and role-plays. These four speaking activities will in the materials developed. Also, these speaking activities enable students to practice speaking skills in and after the classroom using WhatsApp by speaking models they need as assigned.

Speaking activities are designed to enable students to work together to share their thoughts, questions, ideas, and solutions in several speaking tasks and exercises. A collaborative learning activity provided through the WAB speaking instructional material helps the students to develop and achieve their communication skills. Learning together allows the students to overcome their speaking anxiety and nervousness, to develop social skills and critical thinking skills, to promote mutual interaction, and to help prepare students for the challenges in the coming era such today has been started very challenging for all students around the globe with the corona virus disease (COVID-19) outbreaks. Students would get used to communicating in English in both situations face to face and online confidently for their future life, where collaborative and communication skills are highly required in many careers (Aliyu, 2017; Trilling \& Fadel, 2009, p. 54).

\section{Speaking Topics}

Table 8 shows 8 (eight) topics out of 15 (fifteen) that must be covered in the WhatsAppbased speaking instructional materials for the Basic Speaking subject, based on the highest to lowest percentages chosen by students. The speaking topics are daily activities (74.6\%), free time activities (64.2), holidays (62.7\%), food and drink (55.2\%), places (52.2\%), family (49.35), people (47.8\%), and books (38.8\%). Eight (8) topics were included in the material 
development, four (4) topics for mid-term part and other four (4) topics for final-term. They were ranked from the highest percentage chosen to the lowest.

Table 8

Speaking topic

\begin{tabular}{lllll}
\hline No & Information & Answer & Frequency & Percentage \\
\hline 1 & Speaking topic & Animal & 21 & 31.3 \\
& Books & 26 & 38.8 \\
& Clothes & 16 & 23.9 \\
& Daily activities & 50 & 74.6 \\
& Free time activities & 43 & 64.2 \\
& Family & 33 & 49.3 \\
& Food and drink & 37 & 55.2 \\
& Holidays & 42 & 62.7 \\
& Jobs & 28 & 41.8 \\
& Movies & 27 & 40.3 \\
& Places & 35 & 52.2 \\
& People & 32 & 47.8 \\
& Shopping & 15 & 22.4 \\
& Time & 18 & 26.9 \\
& Weather & 16 & 23.9 \\
\hline
\end{tabular}

Note: students could choose more than one responss for the topics they like most to study

Daily topics for Basic Speaking subject are designed from the most preferred topics that students want to the least topics chosen. Familiar daily topics enable students to talk actively and can easily transfer their previous knowledge comprehensively and communicatively. Daily topics are required by students, particularly university students, in their academic lives and everyday tasks (Nizam, Musa, \& Wahi, 2010). The decision about sequencing the course contents in terms of the Basic Speaking topics is taken based on 'need' criteria because the topics are arranged in order of importance to the students' needs in personal and social lives (Richards, 2001). Besides, the topics for the WABSIM need to be sequenced in order to get logical relationships from one to the other topics according to a theme or storyline (stated by a lecturer in the interview). The logical sequence of the topics was then linked to the grammar rules to be taught and practiced altogether in classroom interactions.

\section{Material Adaptation and Readiness to Utilize WhatsApp}

Table 9 shows that students $(73.5 \%)$ agreed with both materials made by the lecturer herself and materials adapted from the existing books or from up-to-date websites. In addition, they agreed with the plan for developing speaking instructional resources in WhatsApp-based 
form. The integration of WhatsApp in teaching speech for conversation supports the learning and teaching in the classroom and beyond the classroom. Yafuz (2017) claim that WhatsApp messenger improve the homogeneity of students' success in EFL learning. In addition, WhatsApp isequipped with a conversation platform that allows the development of relationships (Solomon and Schrum, 2017).

\section{Table 9}

Material adaptation and readiness to utilize WhatsApp

\begin{tabular}{|c|c|c|c|c|}
\hline No & Information & Answer & Frequency & Percentage \\
\hline \multirow[t]{2}{*}{1} & WhatsApp-based speaking & Agree & 63 & 92.6 \\
\hline & $\begin{array}{l}\text { communication and } \\
\text { connection }\end{array}$ & Disagree & 5 & 7.4 \\
\hline \multirow[t]{2}{*}{2} & Existing speaking material & Made by the lecturer & 26 & 38.2 \\
\hline & & $\begin{array}{l}\text { Adapted from the existing } \\
\text { books or materials from } \\
\text { websites }\end{array}$ & 42 & 61.8 \\
\hline \multirow[t]{3}{*}{3} & $\begin{array}{l}\text { Speaking materials are } \\
\text { needed }\end{array}$ & $\begin{array}{l}\text { Materials made by the } \\
\text { lecturer }\end{array}$ & 8 & 11.8 \\
\hline & & $\begin{array}{l}\text { Materials adapted from } \\
\text { existing books or websites }\end{array}$ & 10 & 14.7 \\
\hline & & $\begin{array}{l}\text { Both materials made by the } \\
\text { lecturer and materials adapted } \\
\text { from existing books or } \\
\text { websites }\end{array}$ & 50 & 73.5 \\
\hline
\end{tabular}

Researchers would consider more by linking all items analyzed in this analysis phase. Besides, they agreed with the plan for developing speaking instructional resources in WAB instructions form. The integration of WhatsApp in teaching speaking for daily conversation supports the teaching and learning inside and outside the classroom.

WhatsApp, as the platform for communication, has facilities that provide features to address students' needs. The features such as recordings and callings in the form of audio and video would help engage students to speak more, and this could improve students' interpersonal communication with the easy features available (Boczek and Koppers, 2020). 
WhatsApp as a social medium enables students to collaborate, communicate, and connect with one person at the same time or at the particular times, and also with a group of people in the form of a group WhatsApp. Both formal and informal learning materials will be provided in balance when the materials are in the design and development phase.

\section{Conclusion}

Data resulting from the needs analysis questionnaire informed the researchers of key issues to be considered in constructing WABSIM for implementation and evaluation in the next phase of this project. Students' preferences and learning goals can be integrated with perspectives from the mobile learning literature and the affordances of WhatsApp to facilitate communication, collaboration and interaction in ways that have the potential to accelerate English language learning on the part of university students. There would be value in conducting similar needs analyses for other mobile learning instructional material development processes internationally, both for comparison with the Indonesian results here and in order to inform those development processes.

\section{Acknowledgement}

This study is funded by Indonesian endowment fund for education of educational fund management institution (LPDP) in 2020. 


\section{References}

Afful, B., \& Akrong, R. (2019). WhatsApp and academic performance among undergraduate students in Ghana: Evidence from the University of Cape Coast. Journal of Education for Business, DOI: 10.1080/08832323.2019.1644276

Ahad, A., \& Lim, A. (2014). Convenience or nuisance?: The 'WhatsApp' dilemma. Procedia - Social and Behavioral Sciences 155, 189 - 196

Albino, G. (2017). Improving speaking fluency in a task-based language teaching approach: The case of EFL learners at PUNIV-Cazenga. SAGE Open, 7(2), 1-11. https://doi.org/10.1177/2158244017691077

Aliyu, M. M. (2017). Developing oral communication skills through collaborative learning: Implications for Nigerian teachers. International Journal of English Literature and Social Sciences, 2(5), 127-130. https://doi.org/10.24001/ijels.2.5.15

Arif, A. (2019). Development of Mobile Learning Framework for ESAP for Technical and Engineering Context. Asian EFL Journal, 23 (6.3). Retrieved from https://www.elejournals.com/asian-efl-journal/volume-23-issue-6-3/

Astuti, P., \& Lammers, J. C. (2017). Individual accountability in cooperative learning: More opportunities to produce spoken English. Indonesian Journal of Applied Linguistics, 7(1), 215-229. https://doi.org/10.17509/ijal.v7i1.6878

Awada, G. (2016). Effect on Whatsapp on critique writing proficiency and perceptions toward learning. Cogent $\quad$ Education, $3: 1264173, \quad 1-25$. http://dx.doi.org/10.1080/2331186X.2016.1264173.

Boczek , K., \& Koppers, L. (2020). What's New about Whatsapp for News? A Mixed-Method Study on News Outlets' Strategies for Using WhatsApp. Digital Journalism, 8:1, 126144, DOI: $10.1080 / 21670811.2019 .1692685$

Bahadorfar, M., \& Omidvar, R. (2014). Technology in teaching speaking skill. Acme International Journal of Multidisciplinary Research, 2(4), 9-13.

Brown, J. D. (1995). The elements of language curriculum: A systematic approach to program development. Boston: Heinle and Heinle Publisher.

Brown, H. Douglas. (2004). Teaching by Principles an Interactive Approach to Language Pedagogy. Longman

Karademir, T, Alper, A, Soğuksu, A. F \& Karababa Z.C. (2019) The development and evaluation of self-directed digital learning material development platform for foreign 
language

education, Interactive

Learning

Environments, DOI: 10.1080/10494820.2019.1593199

Kietzmann, J. H., Hermkens, K., McCarthy, I. P., \& Silvestre, B. S. (2011). Social media? Get serious! Understanding the functional building blocks of social media. Business horizons, 54(3), 241-251. DOI: 10.12691/education-3-10-20

Kukulska-Hulme, A., Norris, L., and Donohue, J. (2015). Mobile pedagogy for English language teaching: a guide for teachers. British council 2015, London. Retrieved from http://englishagenda.britishcouncil.org/sites/ec/files/E485\%20Mobile\%20pedagogy\% 20for\%20ELT_FINAL_v2.pdf

Mackey, A. (2016). Sticky e/motional connections: young people, social media, and the reorientation of affect. Safundi, 17:2, 156-173, DOI: 10.1080/17533171.2016.1176398

Madge, C., Breines, M.R., Dalu, M.T.B., Gunter, A., Mittelmeier, J., Prinsloo, P., \& Raghuram, P. (2019). WhatsApp use among African international distance education (IDE) students: transferring, translating and transforming educational experiences, Learning, Media and Technology, 44:3, 267- 82, DOI: 10.1080/17439884.2019.1628048

Maulina, M. (2018). Gender differences in language development, acquisition, comprehension, and production. Proceeding of the 65th TEFLIN International Conference, Universitas Negeri Makassar, Indonesia 12-14 July 2018, Vol. 65. No. 1. 180-184.

Maulina, Noni, N., \& Basri, M. (2019). WhatsApp Audio and Video Chat-Based in Stimulating Students' Self-Confidence and Motivation to Speak English. Asian EFL Journal, 23 (6.3). Retrieved from https://www.elejournals.com/asian-efl-journal/volume-23-issue6-3/

Maming, K., Saleh, N.J., \& Yassi, A.H. (2020). A Preliminary Study on Teacher's Voices: Their Problems in ELT and Content-Based Instruction (CBI. The Journal of Asia TEFL, 17(2), 707-714.

Minalla, A.A. (2018). The effect of WhatsApp chat group in enhancing EFL learners' verbal interaction outside classroom context. English Language Teaching, 11(3), 1-7. URL: http://doi.org/10.5539/elt.v11n3p1

Munir. (2017). Pembelajaran Digital. Bandung: Alfabeta.

Nation, I. S. P. and Macalister, J. (2010). Language curriculum design. New York: Routledge

Nizam, A. S., Musa, N. C., \& Wahi, W. (2010). Information literacy abilities in ESL classrooms. Asean Journal of Teaching and Learning in Higher Education, 2(2), 5265. 
Pavlik \& MacIntoch, John and Shawn. (2015). Converging Media 4th Edition. New York, NY: Oxford University Press. p. 189. ISBN 978-0-19-934230-3.

Piskurich, G.M. (2015). Rapid Instructional Design, Learning ID Fast and Right (Third Edition). New Jersey: John Wiley \& Sons, Inc.

Popescu, A. (2011). Assessment of mobile learning contribution and practices in a lifelong learning society. International Journal of Arts \& Sciences, 4(8), 81-92. Retrieved from https://search.proquest.com/docview/908315097?accountid=62694

Richards, J. C. (2001). Curriculum Development in Language Teaching. Cambridge: Cambridge University Press.

Sakkir, G. (2016). Interest and Writing Skill of the University Students on Using Social MediaFacebook in Writing Class (STKIP MuhammadiyahRappang, Indonesia). Asian EFL Journal (Second Language Acquisition-Academic Research) TESOL Indonesia International Conference Edition (Vol. 2, pp. 178-188).

Solomon, G., \& Schrum, L. (2007). Web 2.0: New tools, new schools. Eugne, OR: International Society for Technology in Education, 9(2).

Speroff, Y. (2016). Using whatsapp for speaking and listening practice [Blog Post]. Retrieved from yuliyasperoffblog.wordpress.com.

Sun, C. (2015). The cultivation of cross-cultural communication competence in oral English teaching practice. English Language Teaching, 8(12), 7-10. https://doi.org/10.5539/elt.v8n12p7

Thornbury, S. (2005). How to teach speaking. Harlow, England: Longman.

Tomlinson, B. (2011). Material Development in Language Teaching ( $2^{\text {nd }}$ Ed.). Cambridge: Cambridge University Press.

Trilling, B., \& Fadel, C. (2009). 21st -century skills: Learning for life in our times. San Francisco: Jossey-Bass.

Vygotsky, L. S. (1978). Mind in society: The development of higher psychological processes. Cambridge. MA: Harvard University Press.

Willing, K. (1988). Learning Styles in Adult Migrant Education. Australia: NCRC Research Series

Yavuz, F. (2016). Do Smartphones Spur or Deter Learning: A WhatsApp Case Study. International Journal of Educational Sciences, 15:3, 408415, DOI: 10.1080/09751122.2016.11890551 